\title{
Farklı Bilgelik Yaklaşımları Açısından “Ömür Dediğin” Belgeselinin Analizi
}

\author{
Gülten ÜNAL*
}

\begin{abstract}
$\ddot{O} z$
Bilgelik, tanımı üzerinde bir fikir birliği olmamakla birlikte, sosyal, bilişsel ve duygusal alanlardaki bilgi ve deneyimlerinin bireyin hem kendi hayatına hem de diğerlerinin hayatlarına yansımalarını içeren bir kavramdır. Yaşla birlikte artışı doğrusal olmayan ve farklı yaklaşımlarla ele alınmaya çalışılan bu kavram, ulusal alanyazında yeteri kadar ele alınmamıştı. Bu araştırmanın amacı, uluslararası alanyazındaki üç farklı bilgelik yaklaşımı çerçevesinde "Ömür Dediğin" isimli belgeselin 170. Bölümünün kısmen incelenmesini içermektedir. Bu doğrultuda, araştırmada MORE Bilgelik Modeli, Grossman'a göre bilgelik uygulamaları ve Ardelt'e göre bilgelik yaklaşımı kullanılarak 80 yaşındaki bir kadının kendi dilinden anlattığı hayat hikâyesi üzerinden analizler gerçekleştirilmiştir. Araştırmanın sonuçları ele alınan belgeselde üç farklı bilgelik yaklaşımından da farklı değişkenler olduğunu göstermektedir. Neticede, bu araştırmada ulusal çerçevede bir bilgelik modeli geliştirilmesi ve uygulamalı olarak bilgeliğin hayata katkısının sunulmasının öneminden bahsedilmiştir.
\end{abstract}

Anahtar Kelimeler: Bilgelik, Yaşlılık, Bilgelik Yaklaşımları, Belgesel Analizi, “Ömür Dediğin”

\section{Analysis of the Documentary "Ömür Dediğin" in Terms of Different Approaches to Wisdom}

\begin{abstract}
Although there is no consensus on its definition, wisdom is a concept that includes the reflections of the knowledge and experiences in social, cognitive and emotional areas to both the individual's own life and the lives of others. Wisdom does not increase with age and it has been tried to be handled with different approaches. But still it has not been adequately addressed in the national literature. The aim of this research is to examine the part of the $170^{\text {th }}$ episode of the documentary named "Ömür Dediğin" within the framework of three different wisdom approaches in the international literature. Accordingly, analyzes were carried out on the life story of an 80-year-old woman by using the MORE Wisdom Model, wisdom practices according to Grossman and wisdom approach according to Ardelt. The results of this study show that there are different variables from three different wisdom approaches in the discussed documentary. As a result, it was proposed to develop a wisdom model in the national framework and to present the contribution of wisdom to life in practice.
\end{abstract}

Keywords: Wisdom, Elderly, Approaches to Wisdom, Documentary Analysis, "Ömür Dediğin”

Geliş/Received: 01.10 .2020

Kabul/Accepted: 22.06 .2021

*Bu çalışmada, katılımcılardan veri toplanmadığı için etik izne gerek bulunmamaktadır.

\footnotetext{
*Dr. Öğr. Üyesi, Ankara Yıldırım Beyazıt Üniversitesi, İnsan ve Toplum Bilimleri Fakültesi, Psikoloji Bölümü, gunal@ybu.edu.tr ORCID ID: 0000-0003-1000-952X

(Makale türü: Araştırma makalesi)
} 


\section{Giriş}

Bilgelik, tanımı üzerinde henüz uzlaşılmamış olan ve hayatın bilişsel, sosyal ve duygusal alanlarında bireyin deneyimlerinin kendi hayatına ve diğerlerinin hayatlarına yansımalarını içeren çok yönlü bir kavramdır. Bilgelik bu çok yönlü doğası nedeniyle (Ardelt, 2003, s.276), araştırmacının hipotezleri ve yönelimine bağlı olarak farklı modellerde ele alınma eğilimindedir. Bilgelik, güncel tanımlarından birinde "insan yaşamının temel sorunları hakkında hem geniş ve derin hem de örtük ve açık olan deneyime dayalı bir bilgi bütünü” olarak tanımlanmaktadır (Weststrate ve Glück, 2017, s. 801).

$\mathrm{Bu}$ araştırmada, uluslararası alanyazındaki üç farklı bilgelik yaklaşımı (MORE Bilgelik Modeli, Grossman'a göre bilgelik uygulamaları ve Ardelt'e göre bilgelik yaklaşımı) yaşlılığa dair bir içerik üzerinden doküman analizi yöntemi ile ele alınmıştır. Çalışmada doküman olarak kullanılan "Ömür Dediğin" belgeseli, TRT Haber kanalında haftalık olarak yayınlanan ve özellikle yaşlı kişilerin hayatlarını onların kendi söylemleri üzerinden ele alan bir yapımdır (https://www.trt1.com.tr/omur-dedigin). Bilgelikle bazen olumlu yönde ele alınan (örn., Sternberg, 2005; Worthy, Gorlick, Pacheco, Schnyer ve Maddox, 2011) bazen de durağan olarak kaldığ1 düşünülen (örn., Baltes ve Staudinger, 2000; Staudinger ve Glück, 2011) "yaşl1lık" bu çalışmanın hedef örneklemine işaret etmektedir. Bu nedenle, bu araştırmada "Ömür Dediğin" isimli belgeselin farklı bilgelik yaklaşımları üzerinden incelenmesi hedeflenmiştir.

Belgeseller, popüler hafizaya ve sosyal tarihe yeni boyutlar katan dünyayı temsil ederek onunla ilişki kuran önemli birer yapıdırlar. Bu bakımdan, belgeseller bize hem tanınabilir bir aşinalık taşıyan dünyanın bir benzerini ya da tasvirini sunarken diğer yandan dünyayı farklı açılardan temsil edebilmektedirler (Nichols, 2001, s. 2-4). Bu bağlamda, bu araştırmada "Ömür Dediğin" belgeselinin bir bölümünün kısmen incelenmesi ile hem belgeselde sunulan yaşl1lık tasviri üzerinden hem de "yaşlılık" kavramının belgeseldeki "örnek kişiler" tarafından tasviri üzerinden üç farklı bilgelik yaklaşımının incelenmesi amaçlanmıştır.

\section{Literatür Taraması}

\section{Bilgelik Modelleri}

Alanyazında birçok farklı türde bilgelik modeli ve yaklaşımı bulunmaktadır. Bu model ve yaklaşımların başlıcaları "Berlin Bilgelik Paradigması" (Baltes ve Smith, 1990; Baltes ve Staudinger, 2000), Sternberg'in (1998, 2000) bilgelik yaklaşımı, Ardelt'e (2003) göre bilgelik yaklaşımı, Bassett'e (2005) göre bilgelik modeli, “Bilgeliğin Süreç Görünümü” modeli (Yang, 2008), Grossman'a (2012) göre bilgelik uygulamaları, "HERO(E)” bilgelik modeli (Webster, 2014) ve "MORE Bilgelik Modeli”'dir (Glück ve Bluck, 2013). "Berlin Bilgelik Paradigması" 
bilgeliği (zengin olgusal bilgi, yargılama ve tavsiye verme, öngörülemezliğin kabulü gibi) beş farklı kriterden oluşan performansa dayalı bir yaklaşımla ele alırken (Baltes ve Staudinger, 2000), Sternberg'in $(1998,2000)$ bilgelik yaklaşımında bilgelik, zekâ ve yaratıcılığın başarılı bir şekilde kullanılarak herkes için iyiye ulaşmak için değer sistemleri aracılığıyla içsel, kişilerarası ve kişisel olmayan çıkarları dengeleme üzerine kuruludur. Diğer yandan, Ardelt'e (2003) göre bilgelik yaklaşımı bilgeliği bilişsel, duygusal ve yansıtıcı boyutları ile tanımlarken Bassett'e (2005) göre bilgelik modelinde ayırt etme (bilişsel), ilgili olma (duygusal), ilgi çekici (aktif) ve dönüştürücü (yansıtıc1) boyutlar yine Ardelt'in modeline benzer bir şekilde yer almaktadır.

“Bilgeliğin Süreç Görünümü” modelinde Yang (2008) bilgeliği bireyin hem kendisine hem de diğerlerine olumlu katkılar sağlayan bir yaşam süreci olarak ele almaktadır. Grossman'a (2012) göre bilgelik uygulamalarında değişim, uzlaşma, esneklik ve bakış açısı gibi kavramlar ön plana çıkmaktayken bilgelik modellerinden bir diğeri olan "HERO(E)" bilgelik modeli (Webster, 2014) mizah, duygusal düzenleme, hatırlama/yansıtma, açıklık ve deneyiminin kendisini bilgeliğin ana unsurları olarak incelemektedir. Son olarak "MORE Bilgelik Modeli"”nde ise "DAHA FAZLA yaşam deneyimi modeli" ile ustalık, deneyime açıklık, yansıtıcı tutum ve empati ile duygu düzenleme bilgeliğin ana unsurları olarak değerlendirilmektedir (Glück ve Bluck, 2013). Bu araştırma kapsamında, içeriklerinin daha uygulamalı kavramlar kapsaması nedeni ile, MORE bilgelik modeli, Grossmann'a (2012) göre ise bilgelik uygulamaları ve Ardelt'e göre bilgelik yaklaşımı ele alınmıştır.

Glück ve diğerlerinin (2013) geliştirdiği MORE bilgelik modelinde dört ana başlık (ustalık (Mastery), açıklık (Openness), yansıtma (Reflection) ve duygu düzenleme/empati (Empathy)) ve üç yan başlık (yaşam zorluklarıyla yüzleşmek, zorluklarla başa çıkmak ve hayat hikayesi uyumu) bulunmaktadır. Bu ana başlık ve yan başlıkların kesişiminden oluşan alanlarda ise bilgeliğin özelliklerini yansıtan özellikler bulunmaktadır. Tablo 1'de Glück ve diğerlerinin MORE bilgelik modelindeki yer alan bilgilerden yola çıkılarak bir tablo hazırlanmıştır.

Tablo 1: MORE Bilgelik Modeli*

\begin{tabular}{|c|c|c|c|}
\hline Kaynaklar & $\begin{array}{l}\text { Yaşam zorluklarıyla } \\
\text { yüzleşmek }\end{array}$ & Zorluklarla başa çıkmak & Hayat hikâyesi uyumu \\
\hline Ustalık & $\begin{array}{l}* \text { Her türlü zorluğun } \\
\text { üstesinden gelebilme } \\
* \quad \text { Kaçınılmaz ve } \\
\text { olumsuz olaylardan } \\
\text { korkmama }\end{array}$ & $\begin{array}{lll}\text { * Devam eden } & \text { zorluklarla başa } \\
\text { çıabilme } & & \\
* \quad \text { Zorluklarla } & \text { aktif } & \text { olarak } \\
\text { ilgilenebilme ve } & \text { bunlara } & \text { uyum } \\
\text { sağlayabilme } & & \\
\end{array}$ & $\begin{array}{l}\text { * Başa çıkma deneyimlerini } \\
\text { yansitıcı bir ustalık } \\
\text { hikâyesine sahip olma }\end{array}$ \\
\hline Açıklık & $\begin{array}{l}\text { * Yeni bakış açılarıyla } \\
\text { ilgilenebilme }\end{array}$ & $\begin{array}{llll}* \quad \text { Çoklu bakış } & \text { açıları } & \text { ile } \\
\text { ilgilenebilme } & & & \end{array}$ & $\begin{array}{l}\text { * Yeni deneyimlere ve bakış } \\
\text { açllarına dayanarak kendi } \\
\text { hikâyelerini değiştirmeye } \\
\text { açık olma }\end{array}$ \\
\hline
\end{tabular}




\begin{tabular}{|c|c|c|c|}
\hline Yansitma & $\begin{array}{l}\text { * Belirsizliğe tolerans } \\
\text { gösterebilme }\end{array}$ & $\begin{array}{l}\text { * Davranışlarını eleştirel bir şekilde } \\
\text { yansıtabilme }\end{array}$ & $\begin{array}{l}* \text { Yeni anlamlar } \\
\text { çıarabilmek amaciyla } \\
\text { geçmiş deneyimler üzerine } \\
\text { derinlemesine düşünebilme }\end{array}$ \\
\hline $\begin{array}{l}\text { Duygu } \\
\text { Düzenleme } \\
\text { / Empati }\end{array}$ & $\begin{array}{lr}* & \text { Kendilerinin } \\
\text { başkalarının } & \text { duygularını } \\
\text { doğru } & \text { olarak } \\
\text { algilayabilme } & \\
\end{array}$ & $\begin{array}{l}\text { * Durumun gerektirdiği şekilde } \\
\text { duygularını düzenleyebilme }\end{array}$ & $\begin{array}{l}\text { * Geçmişe dönük olarak } \\
\text { duyguları anlayabilme ve } \\
\text { bütünleştirebilme }\end{array}$ \\
\hline
\end{tabular}

Grossmann'a (2012) göre ise bilgelik birçok farklı açıdan uygulamaları içermektedir. Bu uygulamalar aşağıda sıralanmıştır:

Tablo 2: Bilgelik Uygulamalar1*

\begin{tabular}{ll}
\hline \hline Uygulamalar & Açıklama \\
\hline \hline Değişim & Kişinin kendisinin, diğerlerinin ve şeylerin değişebilme olasılığını tanıma \\
Uzlaşma & Uzlaşma arayışı içinde olma \\
Esneklik & Durumlar karşında esneklik gösterebilme \\
Bakış açısı & Durumlar karışışında farklı bakış açıları bulundurabilme \\
Çözüm & Uyuşmazlıklar karşısında çözüm üretebilme \\
Bilginin sınırları & Hayattaki belirsizliği tanıyabilme ve bilgisinin sınırlı olduğunu kabul edebilme \\
\hline \hline \multicolumn{2}{c}{$*$}
\end{tabular}

Son olarak, Ardelt'e (2003) göre bilgelik, bilişsel, yansıtıcı ve duygusal boyutların bir bütünü olarak tanımlanır. Bilgeliğin bilişsel boyutu, bir kişinin yaşamı anlama, olayların özellikle içsel ve kişilerarası konulardaki önemini ve daha derin anlamını anlama yeteneğini ifade eder. Bu yetenek, insan doğasının olumlu ve olumsuz yönleri, bilginin doğasında var olan sınırlar ve yaşamın öngörülemezliği ve belirsizlikleri hakkındaki bilgileri içerir. Bilgeliğin yansıtıcı boyutu, bilgeliğin bilişsel boyutunun gelişmesi için bir ön koşuldur. Yansıtıcı boyutun gelişebilmesi için kişinin kendi farkındalığını ve iç görüsünü geliştirmek için olaylara birçok farklı perspektiften bakarak yansitıcı düşünme ile meşgul olması gerekir. Bilgeliğin duygusal boyutu ise, azalan bir benmerkezcilik ve insanların davranışlarını daha iyi anlamayı, kişinin duygusallığını ve başkalarına karşı tavrını iyileştirme ile sevgiyi artırma eğilimindedir. Bu üç boyut birbirinden bağımsız değildir. Fakat yine de bir kişinin "bilge" olarak kabul edilebilmesi için üç boyutun da kişi de aynı anda mevcut olması gerekir (Ardelt, 2003).

\section{Bilgelik ve Yaşlılık}

Bilge insanların yaşlı olma olasılı̆g 1 daha yüksek iken, bilgelik yaşla birlikte otomatik olarak artmamaktadır (Ardelt, 2000; Strenberg, 2005). Ayrıca, yaşlanmanın bazı bilişsel gerilemelere yol açtığı belirtilse de en iyi kararları verebilmek için gereken içgörü ve bilgelikte kazanımlara da yol açabileceği belirtilmektedir (Worth vd., 2011). 
Bilgece yaşlanmayı etkileyen birçok etken bulunmaktadır. Bunlar; yaşam bilgisi, yaşam olayları, sezgi ve farkındalık, deneyime açıklık, zekâ ve bilişsel fonksiyonlar ve üretkenlik olarak sıralanmıştır (Yıldırım ve Abukan, 2015). Örneğin, (hayatın dönemsel özellerine ait bilgiyi içeren) teorik, (bilginin kullanılması ile oluşan) pratik ve (bilginin samimi bir şekilde diğerlerinin faydasına paylaşılmasıyla ortaya çıkan) üretici yaşam bilgisinin yaşlılıkta bilgelik üzerinde etkili olduğunu belirtilmektedir (Ardelt, 2000). Bireyin yaşam olaylarına bakıldığında ise, zorlayıcı yaşam deneyimleri yaşlılarda bilgeliği yordayabilmektedir (Le, 2008). Yaşama odaklanmış açık bir zihnin olumlu türde enerjiyle hayata devam edebilmesini sağlayan sezgi ve farkındalık, bireylerin yaşlandıklarında bilgelik kazanmalarına yardımcı olabilmektedir (Erçetin, 2007). Ayrıca, yaşlı bilge kişiler hayatlarına dair deneyimlerini başkaları ile paylaşmaktan mutluluk duydukları için deneyime açıklık gibi kişilik özellikleri bilgeliğin önemli bir göstergesi olarak kabul edilebilir (Billig, 2000, aktaran Yıldırım vd., 2015). Diğer yandan zeka, bilgelikle özellikle ayrı kavramlar olarak ele alınmakta, fakat yine de bilgeliğin ayırt edici özelliklerinden birisi olarak değerlendirilmektedir (Jeste vd., 2010). Son olarak, bilge yaşliların kendi hayat deneyimleri ile diğer bireylere rehberlik ederek katkıda bulunabilme özellikleri bilgelik için üretkenlik etkeninin değerini ortaya koymaktadır (Yıldırım vd., 2015).

Yaşl11ıkta bilgeliğin olası öncüllerini çalışan bir araştırmada, erken yetişkinlikte destekleyici bir sosyal çevrenin 40 yıl sonra bile bilgelik üzerinde önemli bir etkisi olduğu bulunmuştur (Ardelt, 2000). Aynı araştırma, erken yaşta oluşan olgunluğun yaşlılıktaki olgunlukla önemli ölçüde ilişkili olmadığını göstermiştir. Sonuçlar, erken yetişkinlik döneminde olumlu bir sosyal çevrenin ve olgun kişilik özelliklerinin, yaşlı katılımcıların sosyal ve psikolojik durumu sabit tutulsa bile, sonraki yıllarda özellikle kadınların yaşamdan memnuniyetini artırma eğiliminde olduğunu ortaya koymuştur. Öte yandan, sosyal çevrenin ve olgun kişilik özelliklerinin erken yetişkinlikteki katılımcıların yaşlılık durumu üzerindeki etkisi, öncelikli olarak düşük statülü işlerde çalışan veya ücretli iş gücünün bir üyesi olmayan kadınlar için çok daha önemli görünmektedir (Ardelt, 2000).

Ayrıca, bilge insanlar diğer insanlardan daha başarılı yaşlanmaktadır (Ardelt, 1997, 2000). Özellikle bilge yaşlı kadınlar yaşamlarının sonraki yıllarında kendi hallerinden daha tatmin, aynı zamanda daha sağlıklı ve daha iyi aile ilişkilerine sahip olma eğilimindedir. Bu bilge kadınlar, kendilerine yardım etmenin yanı sıra, tavsiyeleri, eylemleri ve olumlu örnekleriyle başkalarına da yardım edebilmektedirler (Ardelt, 2000).

$\mathrm{Bu}$ araştırmanın problemini, literatürdeki bilgelik yaklaşımlarının birbiri ile genel olarak örtüşmemesi ve bir birey örnekleminde bile bu bireyden yansıyan bilgelik özelliklerinin farklı bilgelik modellerinden açıları yansıtabileceğini oluşturmaktadır. $\mathrm{Bu}$ problem üzerinden 
araştırmanın amacı ise, “Ömür Dediğin” belgeseli örneği kullanılarak literatürde bulunan üç farklı bilgelik yaklaşımının analiz edilmesidir. Bu çalışmanın alana katkısı, kavramsal olarak bilgeliğin farklı yaklaşımlarla ele alınarak özellikle yaşça büyük bir örneklem üzerinde sonuçlarının yansitilmasidir.

\section{Yöntem}

Bu araştırmada, "Ömür Dediğin" belgesel programı bir doküman olarak ele alınarak programın farklı bilgelik yaklaşımları açısından incelenmesi amaçlamıştır. Araştırmada, nitel araştırma yöntemlerinden doküman incelemesi yaklaşımı kullanılmıştır. Doküman incelemesi yöntemi, üzerinde araştırma yapılan olgu(lar) hakkında bilgi sunan yazılı materyallerin inceleme ve analizini içermektedir (Yıldırım vd., 2006). Araştırmada amaçlı örnekleme yöntemi ile "Ömür Dediğin” belgeselinin 170. Bölümü (yayınlama yılı: Ocak 2019) çalışmanın örneklemi olarak kullanılmıştır.

Bu çalışmada kullanılan veriler, içerik analizi yöntemi ile analiz edilmiştir. Krippendorff (2004) içerik analizini, metinlerden (veya diğer anlamlı konulardan), bu metinlerin kullanımları ve bağlamları incelenerek tekrarlanabilir ve geçerli çıkarımlar yapılabilir bir araştırma tekniği olarak tanımlanmıştır. Bu tekrarlanabilir yapının bazı kıstaslara göre kodlandığı içerik analizi yönteminde, üç farklı bilgelik yaklaşımı ((i) MORE Bilgelik Modeli (Glück vd., 2019), (ii) Grossman'a (2012) göre bilgelik uygulamaları ve (iii) Ardelt'e (2003)'e göre bilgelik yaklaşımı) ana temalar olarak kullanılmıştır. Sonrasında bu ana temaların belirleyici özellikleri ise (esneklik, değişim, açılılı, yansıtma gibi) alt temalar olarak ele alınmıştır. Sonuç olarak da bu alt temalar ile "Ömür Dediğin" belgeselinin 170. bölüm içeriği arasında bağlantılar kurulmuştur. Araştırmada, özetleyici içerik analizi ve niyet-güdü çıkarımları için içerik analizi kullanılmıştır. Özetleyici içerik analizinde "Ömür Dediğin" belgeselinin 170. bölümünün içeriği azaltılarak aynı anlama gelen başka kelimelerle ve/ya cümlelerle açıklanmaya çalışılmıştır (Tavşancıl vd., 2001). Niyet-güdü çıkarımları için içerik analizinde ise, eldeki problemle ilgili olarak güvenilir bir model ya da yaklaşım varsa, doğrudan bu model/yaklaşım kullanılarak incelenen veri ile ilgili analizler yapılabilmektedir (Tavşancıl vd., 2001). Bu araştırmada ise, niyet-güdü çıkarımları için içerik analizi alanyazındaki üç farklı bilgelik yaklaşımı kullanılarak ilgili belgeselin analizi yoluyla yapılmıştır. Çalışmada geçerlik ve güvenirlik önlemleri olarak, eldeki belgesel verisi derinlemesine bir şekilde iki farklı zaman diliminde incelenmiş ve veri araştırmacı tarafından yorumlarken belgeseldeki içerik olduğu gibi ve araştırmacının yorumlarını içermeden yansitılmaya özen gösterilmiştir.

\section{Araştırma Bulguları}


“Ömür Dediğin” belgeseli TRT Haber kanalında haftalık olarak yayınlanan yönetmenliğini Zeliha İlhan Doymuş’un yaptığı, genel olarak yaşı ilerlemiş kişileri hayatlarını kendi öz geçmişleri üzerinden yansıtan bir yapımdır (https://www.trt1.com.tr/omur-dedigin). Bu çerçevede bu araştırmada “Ömür Dediğin” belgeselinin 170. bölümü incelenmiştir.

“Ömür Dediğin” belgeselinin 170. bölümünün ilk konuğu olan Nazik Hanım, kendisi ile görüşme gerçekleştirildiği zaman (2019) 80 yaşındadır ve eşini uzun yıllar önce kaybetmiştir (Bilgelik kavramı için cinsiyet farklılıkları nispeten küçük olarak nitelendirildiğinden (Staudinger vd., 2011), bu çalışmada cinsiyet farklılıklarından bahsedilmemiş ve içeriğinde yalnızca bir kadının bulunduğu bir belgesel bölümü analiz edilmiştir.). Nazik Hanım geçimini hayırseverler tarafından kendisine sağlanan aylıkla sağlamaktadır. Nazik Hanım, hem kısmen anne-babasının durumunun iyi olmadığı, hem de eşinin durumunun iyi olmadığı bir hayat sürmüştür. Ailesinin hayvancılıkla uğraştığından bahseden Nazik Hanım, ilkokulu 3-4 yıl okuduğundan ve o dönemdeki çoğu kimse gibi okutulmadığından bahsetmiştir. Sonrasında evlenen Nazik Hanım hem kendi çocuklarına hem eşinin babasına hem de eşinin iki küçük kardeşine baktığını belirtmiştir.

Başlangıçta, belgeselde Nazik Hanım, eşinin kendisi ile değil, başka biri ile evlenmeyi düşündüğünden bahsetmektedir. Fakat Nazik Hanım bu durumu kabullenmekte ve eşine hakkını helal etmektedir (bkz. “...gene de ben hakkımı helal ediyom.). Fakat, yine de Nazik Hanım, kendi doğruları doğrultusunda eğer eşinin bu durumunu bilseydi, kendisinin eşini "almayacağını" (evlenmeyeceğini) belirtmektedir (bkz. "Sonra (bu durumu bana) dediler ama, o zaman deseler alır mıydım?”). Burada, Nazik Hanım eşini affetme ve açık sözlü olma davranışı üzerinden kendisinin ve eşinin (bilge bir şekilde) "değişebilme olasılığını tanımakta" (Grossman, 2012) ve görüşmenin ilerleyen kısımlarında ise eşini sevdiğini belirtmektedir (" $E$ canım, birbirini sevmesen, anlaşmasan evlenilir mi kuzum? Bir zor eden mi var? Yoook. Askere gitti. Yolunu gözlen mi? İki tane kayınım vardı, küçük. İki de kendi çocuğum, bir de kayınbabam. Bunların yemeği, çamaşırı hep elde yunur. Yapardın, onun hatırı için yapan, değil mi?"). "Değişebilme olasılığını tanıma” özelliği ile Nazik Hanım'ın Grossman'a (2012) göre bilgelik uygulamalarının alt değişkenlerinden birisi olan "değişim” uygulaması ile örtüşen bir söylemde bulunduğunu düşünülebilir.

Nazik Hanım, eşinin ailesinin durumunun iyi olduğundan bahsetmekte, fakat onlardan kendilerine herhangi bir yardım gelmediğini belirtmektedir (“Onların (eşinin babasının) durumu bizden azcık iyiydi kuzum da kayınbaba işte.”). Yine de Nazik Hanım, eşinin ailesi için kötü düşünce ve duygular içeren açıklamalarda bulunmamakta, olayın arka planında neler olabileceğinden bahsetmektedir ("İşste o (kayınpederim) paralardan ne bize kısmet etti ne kendi 
yedi. Rahmetli, yaşl11ığın zorundan $\mathrm{m} 1$ etti? $\mathrm{O}$ seferberlikteki (bir)şeylerini düşündüğünden mi etti?”). Bu bilgilerden yola çıkarak, Nazik Hanım'ın “durumlar karışışında farklı bakış açıları bulundurabilme" yeteneği olduğu söylenebilir (Grossman, 2012). Ayrıca, yine bu açıdan eşinin babasının davranışlarının nedenini anlayabilen Nazik Hanım'ın “duygusal bilgelik boyutu”nun (Ardelt, 2003) gelişmiş olduğundan da söz edilebilir.

Nazik Hanım, devamlı olarak çalıştı̆̆ından bahsetmekte ve bu bilgiyi de yorumsuz olarak karşısına iletmektedir ("Ben kendim çalıştım. İki kayınıma, bir kayınbabama, iki çocuğuma baktım.”). Burada da Nazik Hanım yine "yaşamın zorlukları ile yüzleşirken" "ustalığı" gösterebilmekte, "kaçınılmaz ve olumsuz olaylardan korkmayarak" belki de ailesinin başına gelen en büyük zorluklardan birisi olan "yoksulluk" durumunun üstesinden gelmeye çalışarak bilgeliğin ustalık boyutunu (Glück vd., 2019) yansıtmaktadır.

Belgeselin ilerleyen kısımlarında Nazik Hanım, nişanlıyken evlenmek üzere olduğu eşine kaçtığı için ailesinin kendisiyle küs olduğundan bahsetmiştir. $\mathrm{Bu}$ nedenle ailesiyle görüşemediğini ve hiç barışamadıklarını anlatmıştır. Fakat Nazik Hanım bu hususta doğrudan sitem etmemekte ve yine de olumsuz duygu ve düşüncelerden bahsetmemektedir (“Annem babam vardı da küslerdi işte. Nişanlıyken götürdünüz siz (kızımızı) diye. Bir tek kızımızı diye. Küslerdi annem babam."). Öte yandan, Nazik Hanım bu durum için kendini suçlu bulmakta (“Ama barışmadı babam. Barışmadı (benimle) kızım. Ama haklıydı."), ama yine de kendi yaptığını da bir yaşanmışlık olarak kabul etmiş görünmektedir (“Bir evin bir kızı kaçar mı? Kaçtı işte.”). Burada ise Nazik Hanım ailesinin davranış ve duygularının arkasında yatan nedeni anlayabilmekte ve yine "bilgeliğin duygusal boyut özellikleri"ni (Ardelt, 2003) yansıtmaktadır.

Nazik Hanım, eşini en büyük kızının eski nişanlısının öldürdüğünü ağlayarak fakat soğukkanlı bir şekilde anlatmaktadır (“(Eşim) Yaşıyor dediler. Hastaneye vardık, kanı da bitmiş. Kocam da öyle öldü kuzum. 6 tane çocukla kaldık...”). Eşini kaybettikten sonra ağlaya ağlaya da olsa yaşamaya devam ettiklerini belirtmektedir (“Ağlaya ağlaya kızım, meğer gözyaşı da bitmez imiş.”). Sonrasında, serin ve olumlu bir anlatımla, çocuklarını köy halkının da yardımlarıyla büyüttüğünden ve onların büyümesi için kendi yemeyip onlara yedirdiğinden bahsetmektedir ("Yemeği yaptım da, bir tatlı yemek koydum mu, ben bir öyle açık ekmeğin arasına alıverirdim. Öyle dolanırdım. Çocuklarım yesin doysun diye. Yani, tatı bir şey oldu muydu (dayanamazdım)... Eee, anasın. Her şey üstüne kaldı.”). Devamında ise, Nazik Hanım çok çalışarak hayata devam ederek sorumluluk aldığından ve zorlukların üstesinden gelmeye çalıştığından bahsetmektedir (“Öyle işte. Komşunun desteğiyle derken... Çalıştık. Çalıştık. Çok çalıştık kızım. O çocukları besleyeceğiz diye. İşte öyle öyle 6 çocuk büyüdü.”'). Yine burada da, Nazik Hanım'ın “yaşamın zorluklarıyla yüzleşerek” ve "zorluklarla başa çıkıp bunlara uyum 
sağlayarak" hayatını sürdürdüğü, yani bilgenin daha çok "ustalık" yönünü yansıttı̆̆ (Glück vd., 2019) söylenebilir.

Belgeselin son kısımlarına doğru Nazik Hanım çocuklarına yük olduğunu düşünerek onların yanında kalmamakta ve onlara kendisinin herhangi bir yardımı dokunmadığı için mahcup olduğunu ifade etmektedir (“...(Çocuklarım için) Bir şey yapamadım. (Onlara karşı) Çok mahcup oluyorum...”). Nazik Hanım'ın çocukları için söyledikleri göz önünde bulundurulduğunda, kendisinin "zorluklarla başa çıkarken yansıtma" yapabilmesi yoluyla "kendi davranışlarını eleştirel bir şekilde yaklaşabilmesi” ise kendisinin bilgeliğinin “yansıtma” yönünü (Glück vd., 2019) ortaya koyduğu göstermektedir.

Genel anlamda Nazik Hanım'ın anlattığı kendi yaşam hikâyesinde akıcı bir şekilde bütünlük bulunmaktadır. Nazik Hanım, hayat hikayesiyle hem Ardelt (2003), hem Glück ve diğerlerinin (2013), hem de Grossman'ın (2012) bilgelik yaklaşımlarındaki farklı açıları yansıtabilmektedir. Ardelt'in daha çok duygusal bilgelik boyutunu yansıtan Nazik Hanım, Glück ve Bluck'un bilgelik modelinde ise "ustalık" ve "yansıtma" özelliklerini göstermektedir. Grossman'ın yaklaşımından ise bilgeliğin "değişim” ve "bakış açısı" kavramları öne çıkmaktadır. Nazik Hanım'ın kendi yaşam deneyimlerini hem olumlu bir şekilde ve problem-odaklı olarak yeniden değerlendirebilmesi hem de yaşama bağlılığı ile bilgeliği farklı açılardan yansıtabildiği söylenebilir (Etezadi vd., 2013). Ayrıca, "bilge kadın"ların kendileri ve çevrelerine olan faydaları (Ardelt, 2000) bilgisinden yola çıkıldığında ise, Nazik Hanım'ın hem kendisine hem de ailesi ve çevresine düşünceleri ve davranışları ile faydalı olduğundan da bahsedilebilir.

Ayrıca, araştırmadaki belgeselin içeriğinin "yaş”lı odaklı olması ve genç bireylerle kıyaslandığında, yaşı bireylerin olumsuz bilgilere nazaran olumlu bilgilere daha fazla dikkat etmesi ve bu bilgileri hatırlaması (Reed vd., 2012), Nazik Hanım'ın yaşam olayları her ne kadar olumsuz olsa da bu olaylardan kendisine çıkardığı payın aynı derecede olumsuz olmadığ söylenebilir. Bunun nedeni ise, bireylerin kendilerini bilge hissedebildikleri otobiyografik deneyimlerini hatırladıklarında ve yeniden anlattıklarında, bu kişilerin zorluklarla veya belirsizliklerle yüzleşirken kendilerinin ne kadar etkili olduklarını hissedebilmeleri olabilir (Bluck vd., 2004). Aynı zamanda, bu durum, aslında bu bireylerin geçmişlerini kabul edebilmeleri üzerinden giden bir anlam arayışı ile de açıklanabilir (Durmuş, 2019). İşte bu anlam arayışı ile birey, olumsuz yaşam olaylarına karşı daha sakin kalabilmeyi deneyimleyerek hayatını düzenliyor da olabilir.

Öte yandan, bilgelik seviyeleri bireylerin zorlu yaşam deneyimlerini yansıtarak bunları nasıl işlediğinin bir işlevi olarak kişiden kişiye de değişebilmektedir. Daha bilge bireyler, içindeki bulundukları süreç bazen olumsuz olsa bile, yaşam zorluklarını anlam ve büyümeyi vurgulayan 
araştırmacı bir tarzda işleyebilmektedirler (Weststrate vd., 2017). Bu araştırmada farklı bilgelik yaklaşımları yardımıyla ele alınan Nazik Hanım'ın yaşamı da yine zorlu deneyimlerden sonra, bu deneyimleri yine de şükranla anarak, Nazik Hanım muhtemelen depresyon ve strese karşı koruyabilmekte (Wood vd., 2008) ve onu olumsuz içerikli anılarını yeniden yorumlarken bu yorumlamayı yapacak gücü vermede yardımcı olabilmektedir (Fredrickson vd., 2003).

\section{Sonuç ve Öneriler}

Bilgelik hem günümüz hem de gelecek nesiller için taşıdığı değer nedeniyle, bu kavramın teoride ve uygulamada geniş bakış açıları ile ele alınması büyük önem taşımaktadır. Bu amaçla yapılacak olan çalışmalarda, öncelikli olarak kültürler arası farklılıklarla birlikte yaş değişkenlerine dikkat edilmelidir. Örneğin, bilgelik (özellikle birden fazla bakış açısının tanınması, kişisel bilginin sınırları ve uzlaşmanın önemi gibi özellikler için) Amerikalılarda yaşla birlikte artarken, Japonlarda daha genç ve orta yaşı bireyler, akranları Amerikalılara göre daha bilgece düşünebilmektedir (Grossmann vd., 2012). Diğer yandan ise, büyük şehir, kasaba ve yurt dışı gibi farklı kesimlerde yetişmiş katılımcılarla bilgeliğin çalışılması yine önem taşımaktadır. Ayrıca, bilgelik araştırmalarına farklı sosyo-ekonomik seviyeden ve farklı kişilik özelliklerinden katılımcıların dâhil edilmesi, kavramın daha iyi anlaşılabilmesinde etkili olabilir.

Öte yandan, bilgelik kavramının hem ulusal hem de uluslararası alanda araştırılmasına katkı sağlayabilmek için, bu araştırmada ele alınan bilgelik yaklaşımları ile diğer bilgelik yaklaşımlarının birlikte sentezlenerek ele alınması alana katkı sağlayabilir. Bu sentez yaklaşımların farklı kültür, sosyo-ekonomik seviye, yaş ve cinsiyetten bireylerle yapılacak olan çalışmalarda kullanılması, sonrasında ilgili sonuçlardan hayatın uygulamalı alanlarında faydalanılması önemlidir. Bu çerçevede, bilgeliğe giden yolda elde edilecek yaklaşımların içerdiği değişkenleri, yetişmekte olan nesle bilgi ve davranışsal olarak aktarabilmek için hem eğitsel hem de sosyal sorumluluk projeleri geliştirilmesi önerilebilir. Ayrıca hem hâlihazırda yaşlı olan bireyler hem de yaşlanma süreci içerisindeki bireyler için izlenebilecek uygulamalı yollar (farklı terapi tekniklerinin içeriğinde bilgelik değişkenlerinin kullanılması ve tiyatro, belgesel, film gibi iletişim araçları üzerinden bilge bilgilerin yaygınlığının artırılması gibi), bilgelik kavramını bilişsel, duygusal ve sosyal anlamda daha etkili bir konuma taşıyabilir. Bunlara ek olarak, Türkiye'de yaşayan bireyler üzerinden çıkarılacak bir bilgelik yapısının tekrardan Türkiye toplumda uygulamalı olarak kullanılması ise, hem kuşaklar arası çatışmaları azaltmada hem de gelecek için daha bilge nesillerin yetişmesinde faydalı olabilir. Kendi kültürüne has bir bilgelik yapısı ile büyüyen bir toplumun çocukları, bilgeliğin getireceği daha gelişmiş bir zihin yapısı ve daha dengeli bir şekilde kullanılabilen duygular ile bilişsel olarak da sağlıklı bir yaşlılık dönemi geçirebilirler. Sonuç olarak, çocukların yaşlı yetişkinlerin bilgeliğinden faydalanabildikleri 
derecede, genç nesillerin sonraki yıllarda bilgelik gösterme olasıllı̆ı artabilecektir (Worthy vd., 2011). Bu nedenle, bilgelik ve özellikle yaşlılığa giden yolda bilgeliğin gelişimi ile ilgili çalışmalar yapılması önemlidir.

\section{Kaynaklar}

Ardelt, M. (1997). Wisdom And Life Satisfaction In Old Age. Journal Of Gerontology: Psychological Sciences, 52(1), 360-394. https://doi.org/10.1093/geronb/52B.1.P15

Ardelt, M. (2000). Antecedents And Effects Of Wisdom In Old Age: A Longitudinal Perspective On Aging Well. Research On Aging, 22(4), 360-394. https://doi.org/10.1177/0164027500224003

Ardelt, M. (2003). Empirical Assessment Of A Three-Dimensional Wisdom Scale. Research On Aging, 25(3), 275-324. https://doi.org/10.1177/0164027503025003004

Baltes, P. B. ve Smith, J. (1990). The Psychology Of Wisdom And Its Ontogenesis. R. J. Sternberg (Ed.), Wisdom (ss. 87-120). New York, NY: Cambridge University Press. https://doi.org/10.1017/CBO9781139173704

Baltes, P. B. ve Staudinger, U. M. (2000). Wisdom: A Metaheuristic (Pragmatic) To Orchestrate Mind And Virtue Toward Excellence. American Psychologist, 55, 122-136. https://doi.org/10.1037//0003-066x.55.1.122

Bassett, C. (2005). Emergent Wisdom: Living A Life In Widening Circles. ReVision: A Journal Of Consciousness And Transformation, 27, 6-11. https://doi.org/10.3200/REVN.27.4.6-11

Billig, N. (2000). Üçüncü Bahar Yaşlılık Ve Bilgelik. Ankara: Evrim Yayınevi.

Bluck, S. ve Glück, J. (2004). Making Things Better And Learning A Lesson: Experiencing Wisdom Across The Lifespan. Journal Of Personality, 72(3), 543-572. https://doi.org/10.1111/j.0022-3506.2004.00272.x

Durmuş, D. C. (2019). Effect of Accepting the Past on Finding a Meaning in Life among Turkish Old Age Individuals; Moderating Role of Perceived Social Support. Yayınlanmamış yüksek lisans tezi, Orta Doğu Teknik Üniversitesi Sosyal Bilimler Enstitüsü, Ankara.

Erçetin, Ş. Ş. (2007). Bilgece Yaş Almak. I. Ulusal Yaşlılık Konseyi Kongresi, 1 Ekim, Türkiye Yaşl1lık Konseyi Derneği \& Hacettepe Üniversitesi.

Etezadi, S. ve Pushkar, D. (2013). Why Are Wise People Happier? An Explanatory Model Of Wisdom And Emotional Well-Being In Older Adults. Journal Of Happiness Studies: An Interdisciplinary Forum On Subjective Well-Being, 14(3), 929-950. https://doi.org/10.1007/s10902-012-9362-2

Fredrickson, B.L., Tugade, M.M., Waugh, C.C. ve Larkin, G.R. (2003). What Good Are Positive Emotions In Crises? A Prospective Study Of Resilience And Emotions Following The Terrorist Attacks On The United States On September 11th, 2001. Journal of Personality and Social Psychology, 84, 365-376. https://doi.org/10.1037/0022$\underline{3514.84 .2 .365}$

Glück, J. ve Bluck, S. (2013). The MORE Life Experience Model: A Theory Of The Development Of Personal Wisdom. N. M. Weststrate ve M. Ferrari (Ed.), The Scientific Study Of Personal Wisdom (ss. 75-97). Dordrecht: Springer. https://doi.org/10.1007/978-94-0077987-7 4

Grossmann, I. (2012). Getting Wisdom: Aging, Culture and Perspective. Yayınlanmamış doktora tezi, Michigan Üniversitesi, Michigan. 
Grossmann, I., Karasawa, M., Izumi, S., Na, J., Varnum, M. E., Kitayama, S. ve diğerleri. (2012). Aging And Wisdom: Culture Matters. Psychological Science, 23(10), 1059-1066. https://doi.org/10.1177/0956797612446025

Jeste, D. V., Ardelt, M., Blazer, D., Kraemer, H. C., Vaillant, G. ve Meeks, T. W. (2010). Expert Consensus On Characteristics Of Wisdom: A Delphi Method Study. Gerontologist, 50(5), 668-680. https://doi.org/10.1093/geront/gnq022

Krippendorff, K. (2004). Content Analysis: An Introduction to Its Methodology. Thousand Oaks, California: Sage Publications Inc.

Le, T. N. (2008). Cultural Values, Life Experiences, And Wisdom. The International Journal of Aging \& Human Development, 66, 259-281.

Nichols, B. (2001). Introduction To Documentary. Bloomington and Indianapolis: Indiana University Press.

Reed, A. E. ve Carstensen, L. L. (2012). The Theory Behind The Age-Related Positivity Effect. Frontiers In Emotion Science, 3, Article 339. https://doi.org/10.3389/fpsyg.2012.00339

Staudinger, U. M. ve Glück, J. (2011). Psychological Wisdom Research: Commonalities And Differences In A Growing Field. Annual Review Of Psychology, 62, 215-241. https://doi.org/10.1146/annurev.psych.121208.131659

Sternberg, R. J. (1998). A Balance Theory Of Wisdom. Review Of General Psychology, 2, 347365. https://doi.org/10.1037/1089-2680.2.4.347

Sternberg, R. J. (2000). Handbook Of Intelligence. New York, NY: Cambridge University Press. https://doi.org/10.1017/CBO9780511807947

Sternberg, R. J. (2005). Older But Not Wiser? The Relationship Between Age And Wisdom. Ageing International, 30, 5-26. https://doi.org/10.1007/BF02681005

Tavşancıl, E. ve Aslan, E. (2001). Sözel, Yazılı ve Diğer Materyaller için İçerik Analizi ve Uygulama Örnekleri. İstanbul: Epsilon Yayınevi.

Webster, J. D. (2014). Time To Be Wise: Temporal Perspective And Wisdom. Yayınlanmamış doktora tezi, Twente Üniversitesi, Hollanda.

Weststrate, N. M. ve Glück, J. (2017). Hard-Earned Wisdom: Exploratory Processing Of Difficult Life Experience Is Positively Associated With Wisdom. Developmental Psychology, 53, 800-814. https://doi.org/10.1037/dev0000286

Wood, A. M., Maltby, J., Gillett, R., Linley, P.A. ve Joseph, S. (2008). The Role Of Gratitude In The Development Of Social Support, Stress, And Depression: Two Longitudinal Studies. Journal of Research In Personality, 42, 854-871. https://doi.org/10.1016/j.jrp.2007.11.003

Worthy, D. A., Gorlick, M. A., Pacheco, J. L., Schnyer, D. M. ve Maddox, W. T. (2011). With Age Comes Wisdom: Decision Making In Younger And Older Adults. Psychological Science, 22(11), 1375-1380. https://doi.org/10.1177/0956797611420301

Yang, S. (2008). A Process View Of Wisdom. Journal Of Adult Development, 15, 62-75. https://doi.org/10.1007/s10804-008-9037-8

Yıldırım, A. ve Şimşek, H. (2006). Sosyal Bilimlerde Nitel Araştırma Yöntemleri (5. baskı). Ankara: Seçkin Yayınevi.

Yıldırım, F. ve Abukan, B. (2015). Yaşl11ıkta Bilgelik Konusunda Bir Derleme. Türk Psikoloji Yazılart, 18(35), 1-9. 